\title{
Occlusal Splints in Reversible Occlusal Therapy of Craniomandibular Dysfunction
}

\author{
Vojkan Lazić, Igor Djordjević, Ana Todorović \\ Department of Prosthodontics, School of Dentistry, University of Belgrade, Belgrade, Serbia
}

\begin{abstract}
SUMMARY
Craniomandibular dysfunction (CMD) is a set of structural and functional disorders of different etiology that affects temporomandibular joint (TMJ) and orofacial muscles. The most common etiologic factors are psychogenic, occlusal, trauma and congenital anomalies of craniofacial structures. About $75 \%$ of the examined population have mild symptoms of CMD while $3-4 \%$ have more severe symptoms which require medical attention. The main symptoms why people seek for medical attention are: facial pain which increases with chewing and irradiates in surrounding areas and pain in TMJ which irradiates in the ear canal, temporal area or neck. Painful restriction of mandible during mouth opening and eccentric movements is frequent as well as mandible deviation or deflection. Sound effects in TMJ such as popping or clicking during mouth opening are common. Initial and least invasive therapeutic procedure is reversible occlusal therapy using splints. There are two main types of occlusal splints: stabilization and relaxation. First type of splints works on condyle stabilization in orthopedically stable position; it is superoanterior condylar position in articular fossa with position of intercondylar discs between condyle and articular fossa when working cusps of the antagonists are in maximal contact with the splint. Another type of splint causes disocclussion of posterior teeth and eliminates negative effects of occlusal interference in the intercuspal position or during eccentric mandibular movements. During therapy, occlusal splint temporarily changes occlusal relationships as well as relations within TMJ, causing reduction of CMD symptoms. The best therapeutic effect for reduction of CMD symptoms is achieved by combination of physical therapy and medication.
\end{abstract}

Keywords: craniomandibular dysfunction; reversible occlusal therapy; occlusal splints

\section{INTRODUCTION}

The existence of symptoms of craniomandibular dysfunction (CMD), especially in muscles and TMJ often prevents basic functions of the orofacial system. In addition to the present pain (arthralgia and myalgia), one of the most common signs of CMD is restriction of mandibular movements and inability to achieve the central mandibular position spontaneously. Such conditions can be very persistent; the presence of para-functional movements of mandible

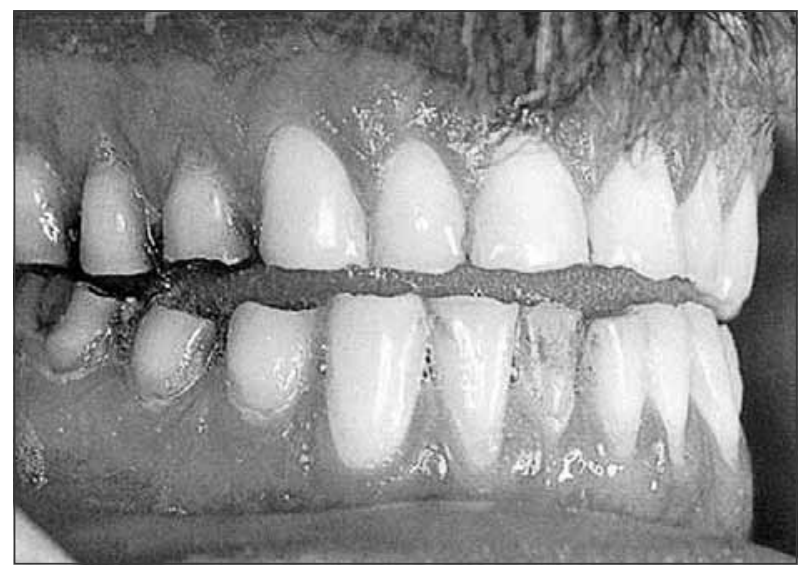

Figure 1. Malocclusion (anterior open bite)

Slika 1. Malokluzija (otvoren zagrižaj u frontu) (day and night bruxism) and/or idiopathic trigeminal neuralgia can further aggravate clinical picture. Given the multifactorial etiology and clinical picture of CMD, to diagnose dysfunction of masticatory muscles and TMJ can be very difficult. Multidisciplinary approach to the therapy is also required. Unfortunately, many clinics neither have possibility to implement all necessary diagnostic procedures nor availability of appropriate therapy. Reversible occlusal therapy using occlusal splints is, therefore, good initial therapy of CMD and it is available to all dentists.

The aim of this study was to demonstrate the possibilities for reversible occlusal therapy using stabilization and relaxation splints.

\section{ETIOLOGY OF CRANIOMANDIBULAR DYSFUNCTION}

CMD is musculoskeletal disease, and often the part of a systemic disease, such as generalized fibromyalgia, or rheumatoid arthritis. The most common symptoms in patients who have CMD are pain in masticatory muscles or temporomandibular joints (TMJ) which irradiates to the region of face and head and abnormal range of movements of the lower jaw with the deviation or deflection and the appearance of sounds in TMJ [1].

Address for correspondence: Vojkan LAZIĆ, Department of Prosthodontics, School of Dentistry, University of Belgrade, Rankeova 4, 11000 Belgrade, Serbia; lazicvid@sezampro.rs 
Etiology of CMD is very complex and multifactorial. Earlier views were based on occlusion as the primary factor in the etiology of dysfunction such as: malocclusion, anterior open bite, overbite greater than $4 \mathrm{~mm}$, discrepancy between central relation and intercuspal position (ICP) greater than $2 \mathrm{~mm}$, loss of lateral occlusal support, the existence of occlusal interference (Figure 1). However, recent findings indicate psychogenic factor as primary, while occlusion can only aggravate clinical picture and complicate treatment of CMD. The most common psychogenic factors are stress, emotional disorders, behavioral disorders, pedantry, mania, extreme responsibility, depression or anxiety $[1,2,3]$.

Epidemiological studies in the United States have indicated that approximately $75 \%$ of the population during lifetime had at least some signs of disturbed orofacial system functions, while $20-25 \%$ had significant symptoms of CMD. Numerous studies indicate that signs and symptoms of CMD are more common and more pronounced in women (3:1 to 9:1) between 15 and 45 years as compared

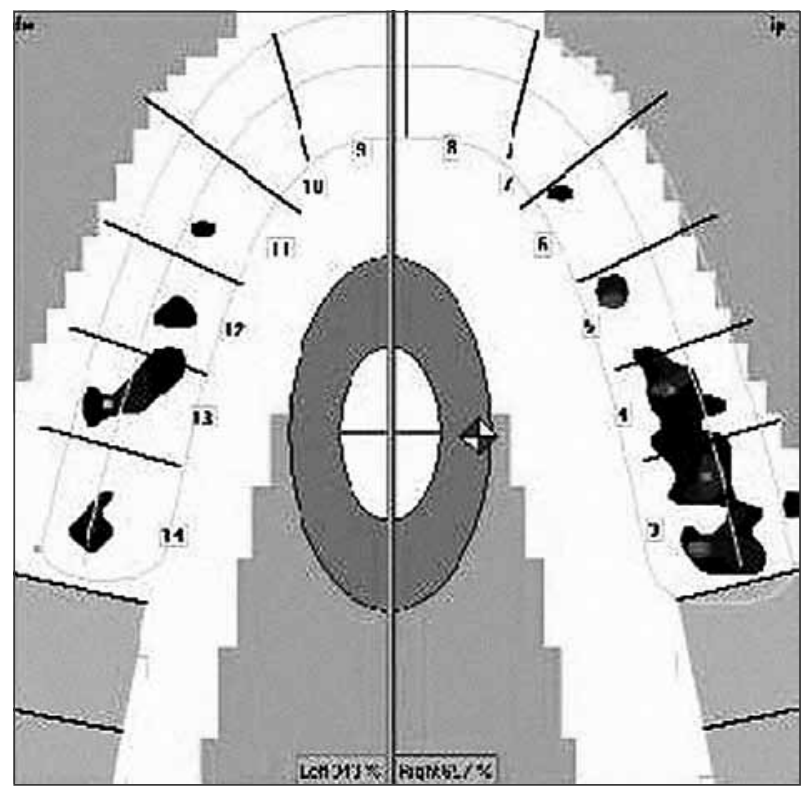

Figure 2. T-Scan II 2D occlusogram

Slika 2. T-Scan II 2D okluzogram

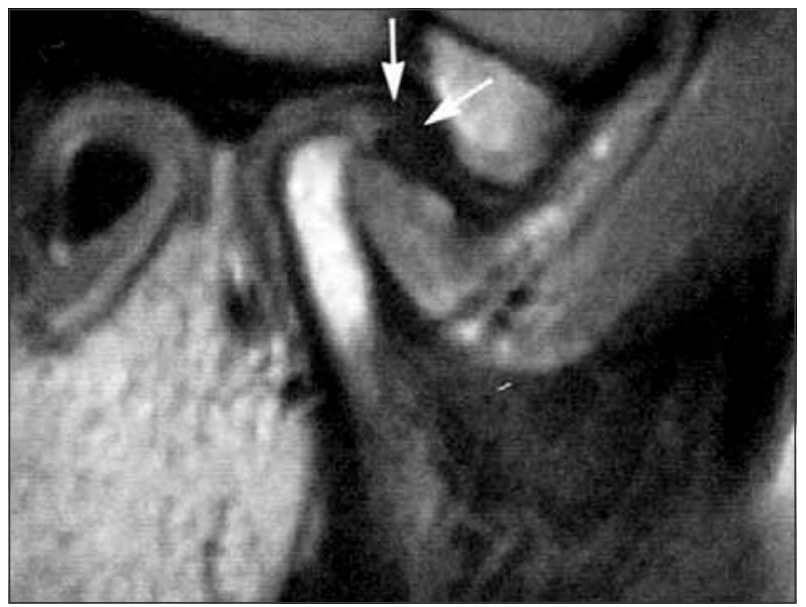

Figure 3. MRI imaging of anterior disc disclocation with reduction Slika 3. NMR snimak anteriorne dislokacije diskusa artikularisa sa redukcijom to men [4]. Although the prevalence of CMD is significant, it was found that only $3-4 \%$ of patients require medical attention and active therapeutic approach, and in 4-7\% help is really needed [4].

\section{DIAGNOSIS OF CRANIOMANDIBULAR DYSFUNCTION}

Diagnosis and treatment of dysfunction should be performed in cooperation with experts from other fields of dentistry and medicine. This multidisciplinary approach to diagnosis and treatment of CMD is needed because of its heterogeneity, multifactorial etiology, symptoms and clinical picture [5]. Diagnostic procedures used for clinical functional analysis of mandibular movements, TMJ and masticatory muscles function analysis are followed by analysis of occlusion (occlusal inspection or computerized oclussography markers or T-Scan III system) (Figure 2) $[5,6]$ and specific diagnostic procedures such as electromyography (EMG) of muscles and radiography of temporomandibular region (CT and MRI) (Figure 3) [1].

\section{THERAPY OF CRANIOMANDIBULAR DYSFUNCTION}

There is a number of therapeutic procedures available for CMD treatment. Some of them are reversible occlusal therapy using splints, irreversible therapy, including fillings, fixed and mobile dental restorations. Also, physical therapy, cryotherapy, transcutaneous electrical nerve stimulation (TENS) therapy, ultrasound, laser therapy and medicamentous therapy could be used $[1,2,3,5,7,8]$. Surgical therapy is performed mostly in cases of ankylosis or trauma of TMJ.

\section{OCCLUSAL SPLINTS}

Occlusal splint therapy is a form of reversible occlusal therapy, which temporarily alters occlusal relationships or relationships within TMJ $[1,2]$. Occlusal splint is an acrylic plate which covers occlusal surfaces of all teeth in maxillary on mandible arch (stabilization splint) $[7,8,9]$. Whenever possible, for greater stability, a splint should be applied in the upper jaw. If properly designed and balanced, it serves as an effective diagnostic tool but also as an active therapeutic tool $[1-5,7,8]$. Literature findings have indicated favorable therapeutic effect of occlusal splints in conjunction with physical therapy in $75-90 \%$ of patients with symptoms and signs of CMD [8]. The mechanism of action in reducing CMD symptoms is not entirely clear.

There are several theories that attempt to explain the mechanism of splint action:

- Occlusal theory - By establishing maximal contact between the teeth of upper and lower jaw, occlusal interference and premature contacts that cause dysfunction are excluded. That way, there is a change in proprioceptive information flow causing the break- 
down and redirecting of reflex mechanisms leading to relaxation of overactive muscles $[9,10]$;

- Theory of high interocclusal relations - It has been shown that temporarily raising the interocclusal distance reduces bioelectrical activity, ie. isometric contraction of the elevators of mandible due to muscle fibers stretching. As a consequence, it will reduce symptoms of CMD $[9,10]$;

- Theory of cognitive awareness - Splint reduces muscle hyperactivity in bruxism. The mechanism is not clear. One possibility is that people who have bruxism react on having something in their mouth by changing their behavior [9];

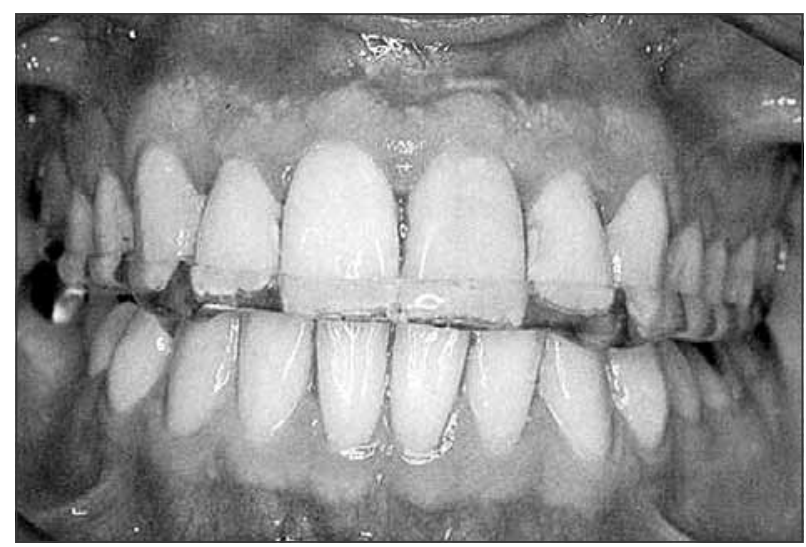

Figure 4. Michigan stabilization splint

Slika 4. "Mičigen" stabilizacioni splint

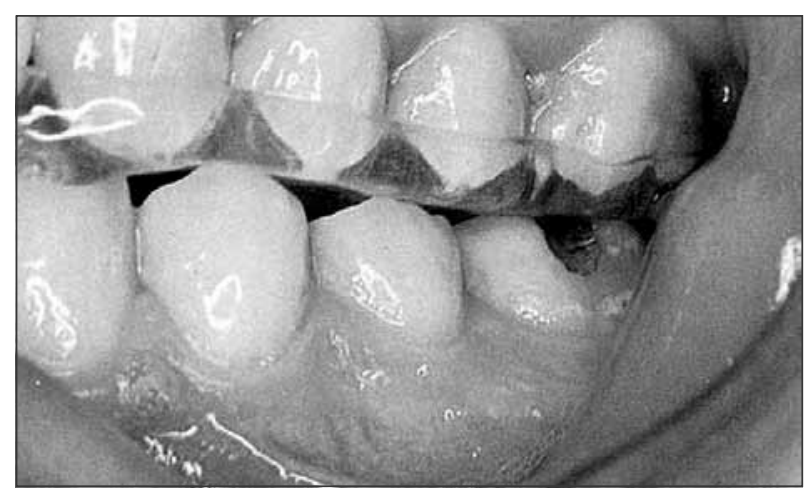

Figure 5. Maximal contact of buccal cusps in opposite jaw with Michigan splint bite plate

Slika 5. Maksimalni kontakti potpornih kvržica antagonista sa pločom „Mičigen” splinta

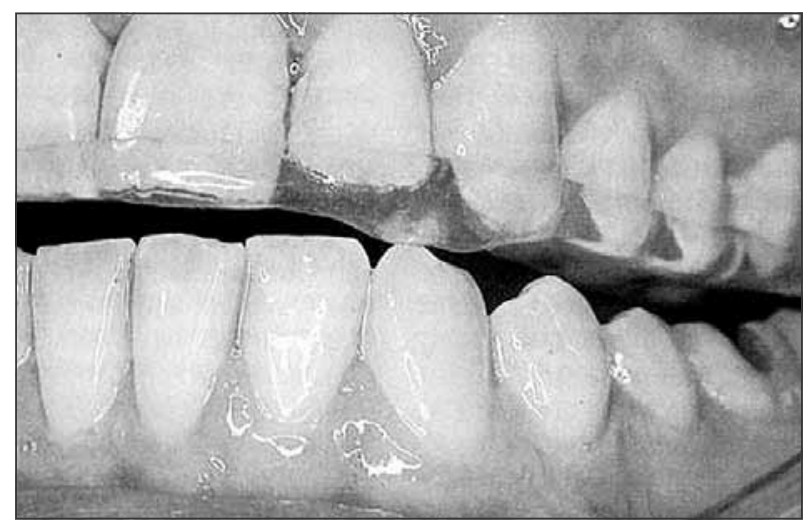

Figure 6. Cuspid guidance to lateral movements

Slika 6. Vođenje očnjakom na laterotruzionu stranu
- Theory of mandible repositioning - The therapy by repositioning splint decreases disc-condyle incoordination causing relief of joint structures. Reconstruction of the occlusion in this position should not be performed since this is temporary therapeutic position [9];

- Placebo theory - Regular splint usage may induce a placebo effect, which causes reduction of symptoms (pain) in muscles and TMJ [9].

Stabilization and repositioning splint are most frequently used in CMD treatment.

Stabilization splint is flat, smooth plate built of transparent polymethyl methacrylate, usually covers teeth in the upper jaw and provides optimal occlusion to the patient (Figure 4) $[1,4,7,9]$. "Michigan" splint, Tanner's splint, occlusal board Schoettl, programmed functional plate by Gausch, synchronizer of masticatory muscles etc. are most commonly used stabilization splints. Therapeutic effects of stabilization splint are usually explained by the fact that they stabilize condyles in physiologically optimal position and establish the harmonious relationship between occlusion and TMJ. Maximal number of contacts between working cusps of lower teeth and splint in the central position of mandible are provided (Figure 5). Splint ensures smooth canine guidance of mandible in protrude and lateral positions. It is believed that canine protected occlusion is optimal occlusion that should be achieved in the treatment of all forms of muscle dysfunction regardless of etiology, because, in that occlusion the lowest electrical activity is measured in mandibular elevators (Figure 6). In a significant percentage signs and symptoms of bruxism are reduced by splints while in $40 \%$ of patients with CMD positive therapeutic effect of stabilization splint is attributed solely to the placebo effect. It is desirable to use splint at night and as much as possible during the day (at least 3-4 hours a day) for at least 3-4 months. During this time, it is necessary to conduct frequent controls, initially once a week and later once a month.

Repositioning splint temporarily stabilize mandible in the selected therapeutic position. The most commonly used is anterior repositioning splint (ARS), which stabilizes mandible in proper protruded position (Figure 7) $[11,12]$. Repositioning therapy is indicated for the treatment of retrodiscal tissue inflammation due to constant injury caused by condyle movements. Therapeutic effect of repositioning splint is explained by temporary changes in condylar position in articular fossa preventing direct contact of condyles with highly vascularized and innervated bilamminar tissue. After splint removal, condyle returns into the previous position. However, for a period of therapy (3-6 month) retrodiscal tissue has opportunity to repair and adapt to be able to stand the pressure of condyle with no harm. Retrodiscal tissue during this period becomes more avascular and fibrotic, sometimes recognized as "pseudo-disc" [11, 12].

Other therapeutic splints include anterior deprogrammers and anterior biting plate (Lucia jig) (Figure 8), posterior biting plate (Interceptor), Pivot splint and soft protective splints for athletes $[7,9]$.

All splints should be adjusted periodically by eliminating occlusal trauma that occurs after early relaxation of 


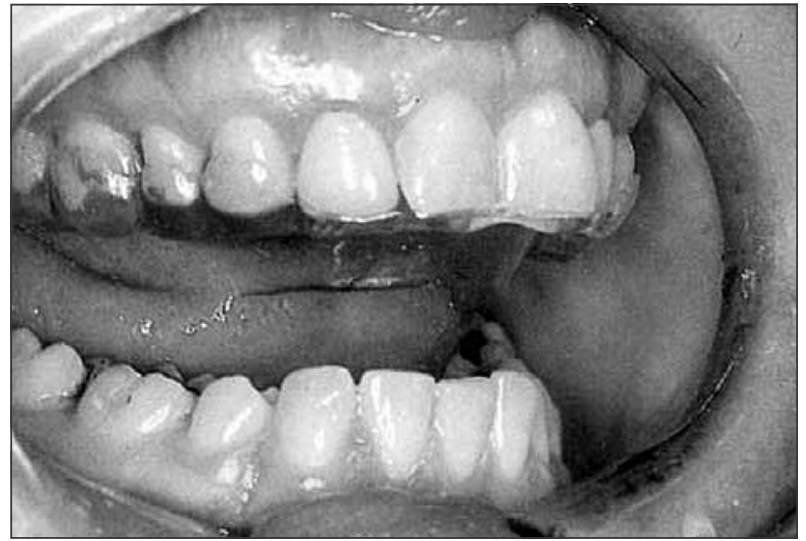

Figure 7. Anterior repositioning splint

Slika 7. Anteriorni repozicioni splint

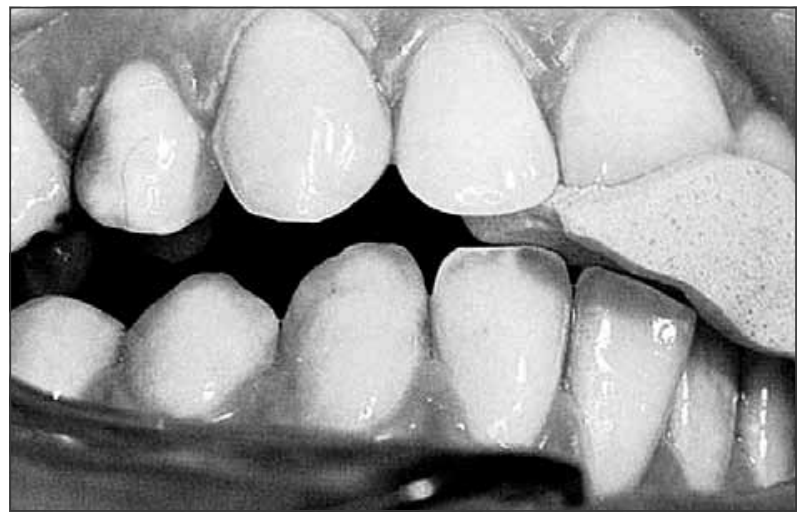

Figure 8. Lucia jig

Slika 8. Lucia jig

the muscles and establishment of normal occlusion [7,9]. Reversible occlusal therapy using splints should be implemented in combination with physiotherapy and medicamentous therapy. Physical therapy and its techniques are used also to reduce pain and fatigue in masticatory muscles in patients with CMD, mandibular para-functional activity and to restore physiological functions of masticatory muscles. Most frequently applied methods of physiotherapy are stretching or lengthening muscle fibers using kinesitherapy, chewing exercises, criotherapy, ultrasound and TENS $[13,18]$.

Medicamentous therapy in reducing symptoms of CMD considers pain reduction with analgesics or non-steroidal anti-inflammatory drugs (Ibuprofen $400 \mathrm{mg}$ or 600 $\mathrm{mg}$ ). Antibiotics are used only in cases of inflammatory processes present in capsule or retrodiscal tissue of TMJ. Benzodiazepines which belong to the group of anxiolytics are used for the treatment of acute spasm of masseteric muscle. They are used as therapeutics, for diagnostic purposes but also as effective central muscle relaxants. Diazepam or nitrazepam are most commonly used benzodiazepines in a dose of $5 \mathrm{mg}$, one hour before bedtime, no longer than a week $[14,15]$. Tricyclic antidepressants are very effective in eliminating chronic pain [16]. They can achieve analgesic effect at doses lower than those used in the treatment of depression [17], they are effective analgesics for patients who don't suffer from depression, and analgesic effect occurs faster than antidepressant effect.
To control night parafunction Amitriptyline (25 mg at bedtime) is recommended.

\section{CONCLUSION}

Reversible occlusal therapy by splints is the initial and least invasive therapy in reducing symptoms of CMD. It is simple and easy to perform. Splints can help in establishing correct anatomical and physiological relations between dental arches and intracapsular components of TMJ. During therapy with occlusal splints, physiological neuromuscular reflexes and harmonious relationship of muscles and TMJ are reestablished, extra and intracapsular pain reduced and regeneration of soft tissue structures within TMJ achieved. After symptoms reduction, definite, irreversible occlusal therapy of CMD can be applied.

\section{REFERENCES}

1. Okeson JP. Management of Temporomandibular Disorders and Occlusion. St. Louis: C.V. Mosby; 1998.

2. Greven M. TMD, bruxism, and occlusion. Am J Orthod Dentofacial Orthop. 2011; 139:424-5.

3. Carlsson GE, Magnusson T. Behandlung Temporomandibulaerer Funktionsstoerungen in der Praxis. Berlin: Quintessenz Verlags$\mathrm{GmbH} ; 2000$.

4. McNeill C. American Academy of Craniomandibular Disorders: Craniomandibular Disorders. Chicago: Quintessence Publishing Co; 1990.

5. Karibe H, Goddard G, McNeill C, Shih ST. Comparison of patient with orofacial pain of different diagnostic categories. Cranio. 2011; 29:138-43.

6. Montgomery MW, Shuman L, Morgan A. T-Scan dental force analysis for routine dental examination. Dent Today. 2011; 30:112-4, 116.

7. Clark GT. Interocclusal appliance therapy. In: Mohl ND, Zarb GA, Carlsson GE, Rugh JD. A Textbook of Occlusion. Chicago, Berlin, London: Quintessence Publ. Co. Inc; 1988. p.359-364.

8. Pertes RA, Gross SG. Clinical Management of Temporomandibular Disorders and Orofacial Pain. Chicago, Berlin, London: Quintessence Publ. Co. Inc; 1995.

9. Gray RJM, Davies SJ, Quayle AA. A clinical approach to temporomandibular disorders. 6 splint therapy. Br Dent ). 1994; 177(4):135-42.

10. Botelho AL, Silva BC, Gentil FH, Sforza C, da Silva MA. Immediate effect of the resilient splint evaluated using surface electromyography in patients with TMD. Cranio. 2010; 28:266-73.

11. Eriksson L, Westesson PL, Rohlin M. Temporomandibular joint saunds in patients with disc displacement. Int J Oral Surg. 1985; 14:428-36.

12. Kalaykova SI, Lobbezoo F, Naeije M. Risk factors for disc displacement with reduction and intermittent locking in adolescents. J Orofac Pain. 2011; 25:153-60.

13. Travell JG, Simons DG. Myofascial Pain and Dysfunction: the Trigger Point Manual. Baltimore: Williams and Wilkins; 1983.

14. Montgomery MT, Nishioka GJ, Rugh JD. Effect of diazepam on noctural masticatory muscle activity. J Dent Res. 1986; 65:452-64.

15. Ganzberg S, Quek SYP. Pharmacotherapy in Clinical Management of Temporomandibular Disorders and Orofacial Pain. Chicago, Berlin, London: Quintessence Publ. Co Inc; 1995.

16. Onghena P, Van Houdenhove B. Antidepressant induced analgesia in chronic non-malignat pain. Pain. 1992; 49:205-19.

17. Sharav $Y$, Singer E, Schmidt E. The analgesis effect of amitriptyline on chronic facial pain. Pain. 1987; 31:199-209.

18. Kalaykova S, Lobbezoo F, Naeije M. Effect of chewing upon disc reduction in the temporomandibular joint. J Orofac Pain. 2011; 25:49-55. 


\title{
Okluzalni splintovi u reverzibilnoj okluzalnoj terapiji kraniomandibularnih disfunkcija
}

\author{
Vojkan Lazić, Igor Đorđević, Ana Todorović \\ Klinika za stomatološku protetiku, Stomatološki fakultet, Univerzitet u Beogradu, Beograd, Srbija
}

\begin{abstract}
KRATAK SADRŽAJ
Kraniomandibularne disfunkcije (KMD) jesu skup strukturnih i funkcijskih poremećaja različite etiologije koji zahvataju temporomandibularne zglobove (TMZ) i orofacijalnu muskulaturu. Najčešći etiološki faktori su psihogeni; slede okluzalni faktori, povrede i kongenitalne anomalije u predelu lica i vilica. Rasprostranjenost blagih simptoma KMD je oko 75\%, dok 3-4\% ispitanika ima teže simptome i potrebna im je lekarska pomoć. Glavne tegobe zbog kojih se osobe sa KMD javljaju lekaru jesu bol u predelu lica koji se pojačava pri žvakanju i širi se u okolne delove i bol u predelu TMZ koji se širi u ušni kanal, temporalno ili u vrat. Česta su i bolna ograničenja pokreta mandibule pri otvaranju usta i ekscentričnim kretnjama sa devijacijom ili defleksijom sredine donje vilice. Neretko se čuju i zvučni efekti preskakanja ili kliktanja u TMZ pri pokretanju donje vilice. Inicijalna i najmanje invazivna terapijska mera je reverzibilna okluzalna terapija splintovima. Okluzalni splintovi mogu biti stabilizacioni i relaksacioni. Prvi imaju zadatak da stabilizuju kondile u ortopedski stabilnom položaju - superoanteriorni položaj kondila u fosi artikularis sa pravilno interponiranim diskusima, kada se potporne kvržice antagonista nalaze u maksimalnom kontaktu sa pločom splinta. Drugi splintovi dovode do disokluzije bočnih zuba i eliminacije štetnog efekta okluzalnih interferenci u interkuspalnom položaju ili pri ekscentričnim kretnjama mandibule. Tokom terapije okluzalnim splintom privremeno se menjaju okluzalni i odnosi unutar TMZ do smanjenja simptoma KMD. Najbolji terapijski efekat suzbijanja simptoma KMD postiže se u kombinaciji s određenim vidovima fizikalne i medikamentne terapije.
\end{abstract}

Ključne reči: kraniomandibularne disfunkcije; reverzibilna okluzalna terapija; okluzalni splintovi

\section{UVOD}

Simptomi kraniomandibularnih disfunkcija (KMD), prevashodno mišićnih i zglobnih, često onemogućavaju izvođenje osnovnih funkcija orofacijalnog sistema. Pored bola (artralgija i mialgija), jedan od najčešćih znakova KMD je ograničenost pokreta mandibule i nemogućnost njenog spontanog dovođenja u centralni položaj. Ovakva stanja mogu biti veoma uporna, a kliničku sliku dodatno pogoršavaju parafunkcionalne aktivnosti mandibule (dnevni i noćni bruksizam) i idiopatske trigeminalne neuralgije. S obzirom na multifaktorsku prirodu i kliničku sliku KMD, dijagnostikovanje poremećaja funkcije mastikatornih mišića i zgloba vilica može biti otežano, a i samo lečenje zahteva multidisciplinarni pristup. Nažalost, u mnogim zdravstvenim ambulantama ne postoje mogućnosti za izvođenje svih neophodnih dijagnostičkih postupaka, niti za primenu odgovarajućeg lečenja. Zato vid reverzibilne okluzalne terapije okluzalnim splintovima, kao inicijalne u lečenju KMD, može da primeni svaki stomatolog u svim uslovima.

Cilj ovog rada bio je da se stručnoj javnosti prikažu osnovne mogućnosti reverzibilne okluzalne terapije, pre svega stabilizacionim i relaksacionim splintovima.

\section{ETIOLOGIJA KRANIOMANDIBULARNIH DISFUNKCIJA}

KMD su oboljenja mišića i zglobova vilica, a neretko i deo nekog sistemskog oboljenja, poput generalizovane fibromialgije, odnosno reumatoidnog artritisa. Najčešći simptomi KMD su bol u mastikatornim mišićima ili temporomandibularnim zglobovima (TMZ) koji se širi u predeo lica i glave, poremećen opseg kretnji donje vilice sa devijacijom ili defleksijom i pojava zvukova u TMZ pri pokretima donje vilice [1].

Etiologija KMD je veoma složena i zavisi od mnogo činilaca. Raniji stavovi su se zasnivali na okluzalnom faktoru kao primarnom u etiologiji disfunkcija, kao što su: malokluzije, otvoren zagrižaj u frontu, preklop prednjih zuba veći od $4 \mathrm{~mm}$, razlika između retrudovanog kontaktnog položaja (RKP) i interkuspalnog položaja (IKP) mandibule veća od $2 \mathrm{~mm}$, gubitak bočne okluzalne potpore, postojanje okluzalnih interferenci (Slika 1). Međutim, novija saznanja ukazuju na psihogeni faktor kao primarni, dok okluzalni faktor može samo produbiti kliničku sliku KMD i otežati lečenje. Najčešći psihogeni faktori su stres, emocionalni poremećaji, poremećaji ponašanja, „pedanterija”, manija, izuzetna odgovornost, depresija i anksioznost $[1,2,3]$.

Epidemiološke studije u Sjedinjenim Američkim Državama pokazuju da se kod skoro $75 \%$ osoba tokom života ispoljava bar neki znak poremećene funkcije orofacijalnog sistema, dok se kod 20-25\% ispitanika javljaju značajni simptomi KMD. Brojne studije ukazuju na to da su znaci i simptomi KMD češći i izraženiji kod žena (od tri do devet puta) starih 15-45 godina nego kod muškaraca [4]. Iako je učestalost KMD značajna, utvrđeno je da samo 3-4\% osoba potraži pomoć lekara, tj. aktivni terapijski pristup, a da je 4-7\% osoba pomoć zaista neophodna [4].

\section{DIJAGNOSTIKOVANJE KRANIOMANDIBULARNIH DISFUNKCIJA}

Dijagnostikovanje i lečenje KMD treba da se izvodi u saradnji sa stručnjacima drugih oblasti stomatologije i medicine. Ovakav multidisciplinarni pristup neophodan je s obzirom na multifaktorsku i heterogenu prirodu KMD, simptome i kliničku sliku [5]. Od dijagnostičkih postupaka primenjuju se: klinička funkcijska analiza pokreta mandibule, analiza funkcije TMZ i mastikatornih mišića, analiza okluzije (inspekcijom i korišćenjem okluzalnih markera ili kompjuterizovana okluzografija T-Scan III sistemom) (Slika 2) [5, 6], kao i specifične dijagnostičke procedure kao što su elektromiografija (EMG) mišića i radiografija temporomandibularne regije (CT i NMR) (Slika 3) [1]. 


\section{LEČENJE KRANIOMANDIBULARNIH DISFUNKCIJA}

Od terapijskih postupaka na raspolaganju je čitav dijapazon različitih metoda. Od vidova okluzalne terapije koriste se reverzibilna terapija okluzalnim splintovima i ireverzibilna terapija ispunima, fiksnim i mobilnim zubnim nadoknadama. Takođe se primenjuju odgovarajuća fizikalna terapija u vidu funkcionalnih vežbi, krioterapija, transkutana električna nervna stimulacija (TENS), ultrazvuk, terapija laserom i medikamentna terapija $[1,2,3,5,7,8]$. Hirurško lečenje se izvodi uglavnom u slučajevima ankiloze viličnog zgloba ili povreda u predelu TMZ.

\section{OKLUZALNI SPLINTOVI}

Okluzalni terapijski splintovi su oblik reverzibilne okluzalne terapije kojima se privremeno menjaju okluzalni odnosi ili odnosi unutar TMZ $[1,2]$. Okluzalni splint ili nagrizna ploča (bedem) je naprava od akrilata koja potpuno (stabilizacioni splint) prekriva grizne površine bočnih zuba, odnosno sečivne ivice prednjih zuba gornje ili donje vilice $[7,8,9]$. Splint se uglavnom postavlja u gornjoj vilici zbog veće stabilnosti. Ukoliko je pravilno dizajniran i uravnotežen, služi kao efikasno dijagnostičko sredstvo i aktivno terapijsko sredstvo [1-5, 7, 8]. Podaci iz literature ukazuju na na povoljne terapijske efekte okluzalnih splintova kod $75-90 \%$ osoba sa simptomima i znacima KMD u sadejstvu sa metodama fizikalne terapije [8]. Zašto su splintovi efikasni u smanjenju simptoma KMD još nije potpuno jasno.

Postoji nekoliko teorija koje pokušavaju da objasne mehanizme dejstva splintova:

- Okluzalna teorija - Splintom se uspostavljaju maksimalni kontaktni okluzalni odnosi, te okluzalne smetnje i prerani kontakti koji izazivaju KMD bivaju isključeni. Na taj način se menja proprioceptivni informativni tok koji utiče na prekid i usmeravanje refleksnih mehanizama, pa dolazi do relaksacije hiperaktivne muskulature $[9,10]$;

- Teorija povišenog interokluzalnog odnosa - Dokazano je da privremeno minimalno povećanje vertikalne dimenzije okluzije smanjuje bioelektričnu aktivnost, tj. izometrijske kontrakcije elevatora, zbog istezanja mišićnih vlakana. Na taj način splintovi smanjuju simptome $\operatorname{KMD}[9,10]$;

- Teorija kognitivne svesnosti - Dnevna i noćna hiperaktivnost mišića kod bruksista se drastično smanjuje nošenjem splinta. Mehanizam dejstva, međutim, nije potpuno jasan. Pretpostavlja se da je razlog smanjenju dnevne hiperaktivnosti mišića kod bruksista sama spoznaja da imaju nešto u ustima što utiče na promenu njihovog ponašanja [9];

- Teorija repozicije mandibule - Terapija repozicionim splintom smanjuje diskusno-kondilne inkoordinacije i rasterećenja zglobnih struktura. Rekonstrukcija okluzije u ovom položaju donje vilice se ne vrši, pošto je to privremeni terapijski položaj [9];

- Teorija placebo efekta - Konačno nošenje okluzalnog splinta može da podstakne placebo efekat koji utiče na smanjenje simptoma bola u mišićima i viličnom zglobu [9].

U lečenju KMD najčešće se koriste stabilizacioni i repozicioni splintovi.

Stabilizacioni splint je ravna, glatka ploča izrađena od transparentnog polimetilmetakrilata koja uglavnom prekriva zube gornje vilice i obezbeđuje optimalnu funkcionalnu okluziju pacijentu (Slika 4) $[1,4,7,9]$. Od stabilizacionih splintova koriste se Mičigen (Michigan) splint, Tanerov (Tanner) splint, okluzalna ploča po Šetlu (Schoettl), programirana funkcionalna ploča po Gošu (Gausch), sinhronizator mastikatornih mišića itd. Terapijski efekti stabilizacionog splinta najčešće se objašnjavaju činjenicom da ove nadoknade stabilizuju kondile $u$ fiziološki optimalnom položaju u zglobnim jamama i uspostavljaju harmoničan odnos između TMZ i okluzije. Splint obezbeđuje maksimalan broj kontakata između potpornih kvržica donjih zuba i splinta u centralnom položaju mandibule (Slika 5). Terapijski splint obezbeđuje nesmetano vođenje očnjakom pri protruziji i laterotruziji mandibule. Smatra se da je vođenje očnjakom optimalan tip vođenja mandibule u lečenju svih oblika mišićnih disfunkcija, bez obzira na njihovo poreklo, jer je pri takvom vođenju u mišićima elevatorima mandibule izmerena najmanja električna aktivnost (Slika 6). Značajan procenat je zabeležen i u smanjenju znakova i simptoma bruksizma, a kod $40 \%$ pacijenata sa KMD pozitivan terapijski učinak stabilizacionog splinta pripisuje se isključivo placebo efektu. Poželjno je da se splint nosi noću i što je moguće više danju (bar tri-četiri sata dnevno) tokom najmanje tri meseca. Za to vreme neophodno je vršiti česte kontrole, u početku na sedam dana, a kasnije na mesec dana.

Repozicioni splintovi privremeno stabilizuju mandibulu u odabranom terapijskom položaju. Najčešće se koristi anteriorni repozicioni splint koji stabilizuje mandibulu u odgovarajućem protruzionom položaju (Slika 7) $[11,12]$. Repoziciona terapija indikovana je kod retrodiscita, gde je retrodiskalno tkivo zapaljeno i otečeno zbog konstantnog povređivanja te zone od strane kondila. Terapijsko dejstvo repozicionog splinta objašnjava se time što privremeno menja položaj kondila u zglobnim jamama i sprečava direktan kontakt kondila sa veoma vaskularizovanim i inervisanim tkivom bilaminarne zone. Nakon uklanjanja splinta, kondil se ponovo vraća u pređašnji položaj. Činjenica je, međutim, da u periodu od tri meseca do šest meseci, koliko traje ova terapija, retrodiskalno tkivo pretrpi niz reparatornih i adaptivnih promena i tako ojača da kontakt s kondilom više ne izaziva bol. Retrodiskalno tkivo u tom periodu postaje fibrotično i avaskularno, pa ga mnogi nazivaju pseudodiskusom $[11,12]$.

U ostale terapijske splintove ubrajaju se anteriorni deprogramer ili anteriorna nagrizna ploča (Lucia jig) (Slika 8), posteriorna nagrizna ploča (Interceptor), Pivot splint i mekani zaštitni splintovi za sportiste [7, 9].

Sve splintove povremeno treba korigovati, odnosno readaptirati okluzalnu površinu ploče splinta, radi eliminacije prevremenih kontakata koji nastaju opuštanjem mišića i uspostavljanjem normalnog odnosa vilica [7, 9].

Reverzibilnu okluzalnu terapiju splintovima neophodno je sprovoditi u kombinaciji s određenim vrstama fizikalne i medikamentne terapije. Fizikalna terapija i njene tehnike koriste se takođe u suzbijanju simptoma bola i zamora u mastikatornim mišićima kod osoba sa KMD, parafunkcionalnom aktivnošću mandibule i vraćanjem mišića u fiziološko stanje. Najčešće primenjivane metode fizikalne terapije su razvlačenje ili izduživanje vlakana mišića kinezioterapijom, vežbe žvakanja, zatim krioterapija, terapija ultrazvukom i TENS $[13,18]$.

Medikamentna terapija se primenjuje za smanjenje simptoma KMD, a najčešće se za suzbijanje bola koriste analgetici (analgin) ili nesteroidni antiinflamatorni lekovi (ibuprofen od 400 
mg ili $600 \mathrm{mg}$ ). Antibiotici se primenjuju samo kod zapaljenjskih procesa u kapsuli ili retrodiskalnom tkivu TMZ. Benzodiazepini se koriste za otklanjanje akutnog mišićnog bolnog spazma masetera i pripadaju grupi anksiolitika. Koriste se u terapijske, ali i u dijagnostičke svrhe, kao efikasni centralni miorelaksansi. Najčešće se primenjuju diazepam i nitrazepam u dozi od $5 \mathrm{mg}$ jedan sat pre spavanja, ne duže od nedelju dana [14, 15]. Triciklični antidepresivi veoma efikasno otklanjaju hronične bolove [16]. Činjenica je da ovi antidepresivi imaju analgetički efekat u dozama manjim od onih koje se primenjuju u lečenju depresije [17], da su delotvorni kod osoba koje ne boluju od depresije, te da se analgetički efekat javlja brže nego antidepresivni. Za kontrolu noćnih parafunkcija preporučuje se amitriptilin (25 mg pre spavanja).

\section{ZAKLJUČAK}

Reverzibilna okluzalna terapija splintovima je početna i najmanje invazivna terapijska mera u suzbijanju simptoma KMD. Jednostavna je i lako se izvodi. Pomoću splintova se uspostavljaju fiziološki i pravilni anatomski odnosi između zubnih nizova i intrakapsularno između komponenata viličnog zgloba. Tokom primene okluzalnih splintova uspostavljaju se fiziološki neuromišićni refleksi i harmoničan odnos funkcije mišića i viličnog zgloba kada dolazi do smanjenja simptoma ekstrakapsularnog i intrakapsularnog bola, kao i do regeneracije lediranih mekotkivnih struktura unutar viličnog zgloba. Nakon redukcije simptoma KMD moguće je izvesti uspešnu konačnu ireverzibilnu terapiju na okluzalnom kompleksu. 